\title{
WHATSAPP SEBAGAI MEDIA LITERASI DIGITAL SISWA
}

\author{
${ }^{1}$ Muhammad Wildan Sahidillah, ${ }^{2}$ Prarasto Miftahurrisqi \\ Prodi Pendidikan Bahasa Indonesia Pascasarjana Universitas Sebelas Maret \\ Email:wsahidillah10@student.uns.ac.id,prarasto@student.uns.ac.id
}

\begin{abstract}
Whatsapp is as one of the most influential social media and widely used by people in Indonesia. Students in Indonesia in the digital era are now using gadgets in their daily activities both at school and outside of school. However, most of these students use social media applications, especially Whatsapp, only for social media, whereas in the application, there are benefits that can improve digital literacy skills. The purpose of this research is to find out: 1) the use of whatsapp as the digital literacy media of students and 2) the digital literacy skills of students in terms of language skills. The method used in this study is to refer, note, and study the literature. This research is a qualitative descriptive study. The results of this study are, 1) the level of digital literacy of students with whatsapp social media is still lacking and 2) improvement of students' digital literacy ability in terms of aspects of language ability, namely, listening, speaking, reading, watching, writing, and writing.
\end{abstract}

Keywords: students; digital literacy; social media; language ability; Whatsapp

\begin{abstract}
Abstrak. Whatsapp sebagai salah satu media sosial paling berpengaruh dan banyak digunakan oleh masyarakat di Indonesia. Para siswa di Indonesia pada era digital saat ini sudah menggunakan gawai dalam aktivitas keseharian mereka baik di sekolah maupun di luar sekolah. Namun, sebagian besar pelajar tersebut menggunakan aplikasi media sosial, khususnya Whatsapp, hanyauntuk bermedia sosial saja, padahal di dalam aplikasi tersebut, terdapat manfaat yang bisa meningkatkan kemampuan literasi digital. Tujuan dari penelitian ini adalah untuk mengetahui: 1) penggunaan whatsapp sebagai media literasi digital siswa dan 2) kemampuan literasi digital siswa dilihat dari kemampuan berbahasa. Metode yang digunakan pada penelitian ini adalah simak, catat, dan kajian pustaka. Penelitian ini adalah penelitian deskriptif kualitatif. Hasil penelitian ini yaitu, 1) tingkat literasi digital siswa dengan media sosial whatsapp masih kurang dan 2) peningkatan kemampuan literasi digital siswa ditinjau dari aspek kemampuan berbahasa, yaitu, mendengar, berbicara, membaca, memirsa, dan menulis.
\end{abstract}

Kata kunci: siswa; literasi digital; media sosial; kemampuan berbahasa; Whatsapp

\section{Pendahuluan}

Media sosial sudah menjadi bagian hidup dari masyarakat di dunia, khususnya di Indonesia. Penggunaan media sosial makin hari makin meningkat karena perkembangan dan inovasi digital saat ini. Media sosial menjadi salah satu kebutuhan pokok digital masyarakat di Indonesia. Media sosial terdiri dari WhatApp, Instagram, Facebook, Line, dan sebagainya.
Pengguna internet di Indonesia sangat banyak, dan berdampak pada penggunaan sosial media. Seperti yang dijelaskan oleh Watie (2011:69) muncul dan berkembangnya internet membawa cara komunikasi baru di masyarakat. Media sosial hadir dan merubah paradigma berkomunikasi di masyarakat saat ini. Komunikasi tak terbatas jarak, waktu, dan ruang. Bisa terjadi di mana saja, tanpa harus tatap muka. Bahkan media sosial mampu 
meniadakan status sosial, yang sering kali sebagai penghambat komunikasi.

Pendapat yang lain dikemukakan oleh Mulawarman dan Nurfitri (2017:36), ia menjelaskan bahwa evolusi yang terjadi di bidang teknologi maupun inovasi internet menyebabkan tidak hanya memunculkan media baru saja. Berbagai macam aspek kehidupan manusia, seperti komunikasi maupun interaksi, juga mengalami perubahan yang sebelumnya tidak pernah diduga. Dunia seolah-olah tidak memiliki batasan, sehingga tidak ada kerahasiaan yang bisa ditutupi. Kita bisa mengetahui aktivitas orang lain melalui media sosial, sementara tidak mengenal dan belum pernah bertemu secara tatap muka atau berada di luar jaringan dengan orang tersebut.

Dari beberapa pendapat di atas dapat diambil simpulan bahwa media sosial tidak mengenal ruang dan waktu, memudahkan berkomunikasi dengan orang yang berada di jauh. Media sosial bisa memfasilitasi kita sebagai pengguna media sosial, sehingga kita bisa tahu siapa pun, walapun kita tidak mengenalnya.

Salah satu yang terkena dampak dari penggunaan media sosial adalah siswa. Siswa pada saat ini sudah banyak yang mempunyai media sosial berupa WhatsApp, Instagram, Facebook, Youtube dan sebagainya. Penggunaan media sosial dari siswa tersebut hanya sebatas untuk berkomunikasi dengan teman-teman yang lain saja. Salah satu media sosial yang sering digunakan yaitu, WhatsApp.Mengenai mengapa siswa/remaja lebih banyak menghabiskan waktunya hanya untuk bermedia sosial, seperti pendapat yang dikemukakan oleh Hoechsmann dan Poyntz (2012:24) dengan semua pilihan media yang tersedia saat ini, tidak mengejutkan apabila remaja atau siswa saat ini menjadi seorang yang bisa menguasai banyak media karena lebih bisa menghabiskan waktu dengan media sosial, dibandingkan dengan remaja atau siswa yang lalu.

WhatsApp memiliki berbagaifungsi, di antaranya adalah bisa mengirim pesan, chat grup, berbagi foto, video, dan dokumen.
Namun, penggunaan media sosial tersebut tidak terlalu dimanfaatkan sebagai media literasi oleh siswa. Siswa hanya meluangkan waktu dengan Whatsapp sebagai media sosial sebatas berkirim pesan, foto maupun dokumen yang tidak memuat literasi sama sekali. Akibatnya, siswa cenderung apatis terhadap keberadaan WhatsApp sebagai media sosial yang bisa digunakan untuk media literasi.

Selain itu beberapa contoh di atas, kemampuanliterasisiswadalammemanfaatkan media sosial seperti WhatsApp terlihat dalam penggunaan bahasa. Bahasa yang digunakan adalah bahasa Indonesia yang baik dan benar. Media sosial terutamaWhatsApp, memilikifitur grup, sehingga setiap penggunanya termasuk siswa dapat mengirim pesan secara langsung pada anggota grup dengan menggunakan berbagai ragam bahasa. Namun, siswa hanya memanfaatkan penggunaan bahasa sebatas lingkungan pergaulan terdekat saja. Siswa seringkali tidak menganggap penting penggunaan bahasa Indonesia yang baik dan benar tersebut.

Kegiatan berbahasa Indonesia yang lain semacam membaca, menulis, maupun mendengarkan juga tidak terlalu memberikan efek yang signifikan terhadap kemampuan literasi siswa melalui media sosial WhatsApp. Pemahaman terhadap penggunaan bahasa Indonesia yang baik dan benar bagi perkembangan literasi siswa masih kurang. Maka dari itu, pentingnya penelitian ini adalah untuk mengetahui penggunaan WhatsApp sebagai media literasi digital siswa dan kemampuan literasi digital siswa dilihat dari kemampuan berbahasa.

Literasi digital adalah kemampuan memahami dan menggunakan informasi dari berbagai sumber digital, dan kemampuan menggunakan teknologi dan informasi dari piranti digital secara efektif dan efisien dalam berbagai konteks, seperti akademik, karir, dan kehidupan sehari-hari (Gilster dalam Kurnianingsih, dkk, 2017:62).

Kusuma (2011:402) berpendapat bahwa tidak bisa dipungkiri bahwa Media baru/ media digital ini lebih familiar dengan 
anak muda daripada orang tua maupun guru. Melarang bukan lagi menjadi sebuah pilihan. Menumbuhkan kesadaran untuk bisa melakukan dialog kritis dapat membantu mereka/siswa untuk lebih memahami makna dari pengalaman digital mereka. Dari pendapat Kusuma di atas, dapat ditarik simpulan bahwa orang tua harus selalu memantau, mengawawsi, dan membimbing bagaimana anak menggunakan media sosial, supaya lebih bijak dalam penggunaannya.

\section{Metode Penelitian}

Pendekatan penelitian ini, yaitu, deskriptif kualitatif. Metode penelitian pada penelitian iniadalah simak, catat, dan kajian pustaka.Data dan sumber data pada penelitian ini adalah pendapat atau persepsi dari wawancara pada siswa SMP kelas IX.Teknik pengumpulan data menggunakan teknik wawancara dan observasi. Teknik analisis data menggunakan teknik analisis data interaktif.

\section{Hasil Penelitian dan Pembahasan}

\section{Penggunaan WhatsApp sebagai Media Literasi Digital Siswa}

Berbagi materi pelajaran (menggunakan fitur Forward) WhatsApp memiliki fitur yang bisa menyimpan dokumen dalam bentuk pdf, microsoft word, excel, dan powerpoint. Maka dari itu, apabila menggunakan WhatsApp berbagi dokumen dengan dengan format/ bentuk di atas jauh lebih mudah. Selain bisa digunakan menyimpan dokumen dengan bentuk atau format di atas, WhatsApp juga bisa meneruskan pesan, sehingga memudahkan apabila siswa ingin berbagi dengan teman yang lain. Contoh penerapannya adalah ketika seorang siswa memiki materi yang sudah dirangkum atau dicatat ketika di sekolah, apabila ada teman yang membutuhkan karena catatannya belum lengkap, bisa dibagikan kepada teman-teman yang lain menggunakan fitur forward.Fitur forward memudahkan untuk mengirim atau melanjutkan ke teman yang lain, tanpa harus membuka pada manajer file di gawai.

Namun, perlu diperhatikan bahwa fitur forwad bisa menyebabkan terjadinya penyebaran berita bohong atau hoaks itu cepat tersebar. Maka dari itu, fitur forward pada WhatsApp digunakan seperlunya saja, tidak asal-asalan membagikan sesuatu yang belum jelas kebenarannya. Peran orang tua siswa di sini sangat penting. Orang tua harus memantau apa saja yang didapatkan siswa pada WhatsApp yang digunakannya, sehingga orang tua bisa mewaspadai penyebaran berita yang tidak benar.

\section{Pembelajaran Jarak Jauh (Menggunakan fitur voice note)}

Pembelajaran Jarak Jauh (PJJ) bisa dilakukan oleh siswa dan guru yang tergabung dalam satu grup tertentu.Pembelajaran ini bisa dilakukan sesuai dengan kebutuhan dan kesepakatan dari guru dan siswanya. Pembelajaran Jarak Jauh (PJJ) bisa terjadi, apabila ada pertemuan yang guru itu tidak bisa untuk mengajar, kemudian memberikan pengumuman kepada siswa supaya nanti malam untuk bisa melangsungkan PJJ tersebut.

Pembelajaran Jarak Jauh (PJJ) bisa menggunakan media sosial WhatsApp. WhatsApp digunakan sebagai media untuk berdiskusi. Awalnya guru memberikan materi kepada para siswanya yang ada di grup tersebut, kemudian guru memberikan instruksi untuk mengerjakan soal atau berpendapat mengenai materi tersebut. Ketika siswa mengemukakan gagasan atau pendapatnya, harus disertai dengan nama dan nomor absen, supaya guru bisa memberikan penilaian kepada seluruh siswa yang berpartisipasi di dalam grup secara langsung.

Pembelajaran ini akan lebih menarik apabila semua siswa aktif dalam pembelajaran tersebut. Guru di sini dituntut harus kreatif dalam mengembangkan materi yang akan diajarkan melalui Pembelajaran Jarak Jauh (PJJ) menggunakan WhatsApp. Fitur dari WhatsApp yang lain adalah bisamengirim Voice notes atau perekam suara. Perekam suara bisa digunakan untuk siswa dalam mengemukakan pendapatnya. Apabila ada tes kemampuan berbicara, siswa bisa menggunakan fitur 
voice notes. Penilaian dari guru bisa berupa bagaimana siswa mengutarakan pendapatnya tersebut secaralisan menggunakan fitur voice notes (perekam suara).

Penelitian yang dilakukan oleh Suryadi, dkk (2018) dengan judul Penggunaan Sosial Media WhatsApp dan Pengaruhnya terhadap DisiplinBelajar Peserta Didik pada Mata Pelajaran Pendidikan Agama Islam (StudiKasus di SMK Analisis Kimia YKPI Bogor), menjelaskan bahwa WhatsApp mempengaruhi disiplin belajar siswa, sehingga aktivitas belajar siswa menurun dan lemah dalam mengikuti pembelajaran.

Penelitian di atas dilakukan saat pembelajaran di dalam kelas. Apabila dilakukan dengan metode yang lebih menarik, siswa juga bisa lebih tertarik dalam belajar dan media sosial digunakan sebagai sarana untuk pembelajaran, justru bisa meningkatkan disiplin belajar siswa.Sependapat dengan penelitian dari Alqahtani, dkk (2018), yang berjudul WhatsApp: An Online Platform for University-Level English Language Education, menunjukkan bahwa penggunaan media sosial, seperti WhatsApp dapat memungkinkan siswa untuk memahami dan terlibat dalam menggunakannya sebagai bagian dari pembelajaran.

\section{Berbagi materi melalui Whatsapp Story}

WhatsApp memungkinkan siswa untuk bisa membagikan materi melalui status. Siswa bisa membagikan materi pelajaran atau pengetahuan yang lain dengan menggunakan fitur di WhatsApp, yaitu, WhatsApp Story atau status di WhatsApp. Siswa bisa berbagi foto, video, atau link website menggunakan status.

Status di WhatsApp bisa dilihat apabila siswa saling menyimpan nomor teleponnya, sehingga bisa saling melihat status yang dibuat satu sama lainnya. WhatsApp Story merupakan salah satu media untuk berbagi dan menyimak siswa di luar grup chat yang dimiliki siswa. Berbagi foto, video, atau link website yang mungkin belum diketahui banyak orang, sehingga apabila ada siswa lain yang melihat status tersebut bisa memberikan komentar.
Membalas di status atau memberikan komentar pada status siswa yang lain merupakan salah satu bentuk kemampuan berbahasa siswa. Apabila status tersebut sudah ditanggapi oleh siswa yang lain, maka akan terjadi diskusi, sehingga status di WhatsApp bisa menjadi penting sebagai saran literasi digital siswa.

\section{Peningkatan Kemampuan Literasi Digital Siswa dilihat dari Kemampuan Berbahasa}

a. Mendengar

Mendengar adalah salah satu kemampuan berbahasa siswa yang paling awal.Mendengar identik dengan audio atau suara. Literasi digital menggunakan media sosial WhatsApp bagi siswa bisa meningkatakan kemampuan berbahasa. Media sosial WhatsApp memiliki fitur yaitu, voice notes (perekam suara), yang bisa meningkatakn kemampuan siswa dalam memahami teks/ ungkapan/pendapat dari siswa yang lain.।

\section{b. Berbicara}

Literasi digital siswa berkaitan dengan aspek kemampuan berbahasa yang lain, yaitu berbicara. Aspek berbicara pada siswa bisa meningkat dengan menggunakan media sosial WhatsApp. WhatsApp bisa meningkatkan kemampuan siswa untuk berbicara, didukung dengan menggunakan fitur voice notes atau perekam suara. Fitur voice notes dapat digunakan sebagai penilaian siswa apabila dalam Pembelajaran Jarak Jauh (PJJ) dengan materi mengenai berbicara.

\section{c. Membaca}

Membaca melalui media sosial seperti WhatsApp sangat efisien dan efektif sebagai media literasi digital siswa. Salah satunya adalah bertukar informasi mengenai materi pembelajaran, daftar tugas yang harus 
dikerjakan maupun kisi-kisi ujian. Penyampaian informasi tersebut tersebar secara cepat dan mampu menjangkau seluruh siswa. Kegiatan membaca yang melibatkan media sosial seperti WhatsApp dapat memberikan dampak terhadap perkembangan keterampilan berbahasa bagi siswa.

Pengaruh baiknya adalah sebagai salah satu bentuk inovasi dalam pembelajaran yang dapat memberikan akses cepat langsung dan mudah tanpa perlu biaya banyak. Misalnya, memfotokopi materi pelajaran tersebut, cukup dengan memfoto materi pelajaran saja, kemudian bisa berkirim pesan melalui WhatsApp. Pengaruh buruknya adalah siswa jadi tidak fokus dan mudah beralih atau kecanduan bermedia sosial. Penyebab dari itu semua adalah tidak memanfaatkannya media pembelajaran, tetapi untuk hal-hal lain, seperti membuat status, berkirim pesan gosip, bahkan sampai dengan menyebarkan hoaks. Maka dari itu, siswa dan guru harus saling bersinergi dan berkoordinasi dalam memanfaatkan WhatsApp sebagai media literasi.

\section{d. Memirsa}

Memirsa dalam media sosial, seperti WhatsApp, digunakan untuk melihat kiriman video pembelajaran. Guru dapat memanfaatkan video yang dapat diunduh dari Youtube atau yang tersebar melalui WhatsApp untuk kepentingan pembelajaran. Misalnya, pembelajaran puisi dalam bahasa Indonesia. Pembelajaran seperti itu membutuhkan video sebagai media audio visual yang sudah tentu harus mewajibkan kemapuan memirsa siswa dengan baik dan benar. Selain itu fitur dalam WhatsApp seperti forward, sangat memudahkan bagi siapa pun dalam membagikan pesan berupa video.

\section{e. Menulis}

Menulis dalam media sosial seperti WhatsApp, bisa digunakan untuk pembelajaran media literasi. Cara menumbuhkan kesadaran menulis menggunakan bahasa Indonesia yang baik dan benar melalui media sosial seperti WhatsApp. Penulisan yang paling diperhatikan adalah penggunaan kosakata baku dan tidak baku. Terkadang atau seringkali, siswa dalam menuliskan kata-kata melalui media sosial seperti WhatsApp tidak memperhatikan kaidah-kaidah penggunaan bahasa atau terbatas pada lingkungan terdekatnya saja. Bahasa daerah kadang masih digunakan dalam menulis WhatsApp.

\section{Simpulan}

Penggunaan WhatsApp sebagai media literasi digital siswa meliputi tiga hal, yaitu 1) berbagi materi pelajaran di WhatsApp,fitur forward memudahkan untuk mengirim atau melanjutkan ke teman yang lain, tanpa harus membuka pada manajer file di gawai, 2) Pembelajaran Jarak Jauh (PJJ), fitur dari WhatsApp yang lain adalah bisa mengirim Voice notes atau perekam suara. Perekam suara bisa digunakan untuk siswa dalam mengemukakan pendapatnya. Apabila ada tes kemampuan berbicara, siswa bisa menggunakan fitur voice notes, 3)WhatsApp Story merupakan salah satu media untuk berbagi dan menyimak siswa di luar grup chat yang dimiliki siswa. Berbagi foto, video, atau link website yang mungkin belum diketahui banyak orang, sehingga apabila ada siswa lain yang melihat status tersebut bisa memberikan komentar.

Kemampuan literasi digital siswa berkaitan dengan kemampuan berbahasa siswa, yaitu, 1) mendengar, 2) berbicara, 3) membaca, 4) memirsa, dan menulis. 


\section{Daftar Pustaka}

Alqahtani, M. S., Bhaskar, C. V., Vadakalur Elumalai, K., \& Abumelha, M. (2018). WhatsApp: An Online Platform for University-Level English Language Education. Arab World English Journal, 9(4), 108-121. https://doi.org/10.24093/awej/vol9no4.7

Hoechsmann, Michael \& Stuart R. Poyntz. (2012). Media Literacies: A

Critical Introduction, UK: Blackwell Publishing.

Kurnianingsih, I., Rosini, dan Ismayati, N. (2017). Upaya Peningkatan

Kemampuan Literasi Digital bagi Tenaga Perpustakaan Sekolah dan Wilayah Jakarta Pusat Melalui Pelatihan Literasi Informasi. Jurnal Pengabdian Kepada Masyarakat, 3(1), 6176. https://doi.org/10.22146/jpkm.25370

Kusuma, Rinasari. (2011). Remaja Digital: Literasi dan Etika. In Chatia Hastasari

(Ed.), New Media: Teori dan Aplikasi, Karanganyar: Lindu Pustaka.

Mulawarman, M., \& Nurfitri, A. D. (2017). Perilaku Pengguna Media Sosial

beserta Implikasinya Ditinjau dari Perspektif Psikologi Sosial Terapan. Buletin Psikologi, 25(1), 36-44.https://doi.org/10.22146/buletinpsikologi.22759

Suryadi, E., Ginanjar, M. H., \& Priyatna, M. (2018). Penggunaan Sosial Media

WhatsApp dan Pengaruhnya terhadap Disiplin Belajar Peserta Didik pada Mata Pelajaran Pendidikan Agama Islam. Jurnal Edukasi Islami Jurnal Pendidikan Islam, 07(1), 1-22. https://doi.org/10.30868/EI.V7

Watie, E. D. S. (2011). Komunikasi dan Media Sosial (Communications andSocial Media). The Messenger, 3(1), 69-75. https://doi.org/http://dx.doi.org/10.26623/themessenger. v3i 2.270 